\title{
WOMEN'S IN FITNESS SOCIAL BELONGING AND PHYSICAL ACTIVITY IN THE CONTEXT OF QUALITY OF LIFE
}

Aleksandra Cuprika

Andra Fernate

Leonids Cupriks

Latvian Academy of Sport Education

\begin{abstract}
Forming as many interpersonal relationships as possible is one of the most important goals in peoples' lives. Mutual physical activities create a basis for social belonging. Therefore, the goal of the study is to determine the correlation between the components of social belonging and physical activity among women in fitness. The social belonging analysis was conducted with the use of questionnaires (adopted in Latvian), and a shortened version of IPAQ to determine the levels of physical activity. The components of social belonging were defined, and several weak, but significant, correlations between these components and the level of physical activity were found. According to the data obtained in the current study we can conclude, that social belonging has positive impact on PA. Those, who more often feel the relatedness, satisfactory from interpersonal relationship and inclusion in the social groups are more physically active. In order to evaluate, how the quality of life aspect of social belonging for women in fitness correlates with physical activity, they must be taken into account.
\end{abstract}

Keywords: IPAQ, physical activity, quality of life, social belonging.

\section{Introduction}

Nowadays the importance of a healthy lifestyle has become not only a biological necessity, but more of a social one - by acquiring a status in the society or belonging to a particular group, by improving one's quality of life. The fitness industry as an innovative social practice development instrument facilitates extensive social changes in people. The body becomes not only a basic value, but also a term of achievements in the society. Fitness gives tremendous opportunities to communicate, interact with other participants in the fitness industry - club visitors, coaches, nutrition specialists etc. It helps people to feel included in an active lifestyle community and to satisfy the need for social contacts (Allen, 2003). Fitness provides a number of advantages for women. Several scientific studies on fitness proved that women are able to improve their social belonging due to the development of their body - by developing strength, reducing stereotypes of gender advantages in certain fields (Heywood \& Dworkin, 2003; Dworkin \& Wachs, 2009; Deveaux, 1994; Lenskyj, 1986). In their turn other studies prove that the existing body standards in fitness can lead people to despair, depression and barriers in the society, 
because it is not physiologically possible for all to achieve the slimness parameters (Bartky, 1998).

One of the essential conditions of the theme's topicality is that fitness gives each person the opportunity to express oneself through the body's improvement process, to build their social identity and emotional connection with other people (Walseth, 2006; Walseth \& Fasting, 2004). When a person feels as socially belonging to a particular group, by being together the person has a feeling as if one were in their home, the person feels that one is a part of a united mechanism (Antonsich, 2010).

The goal of the study is to determine the correlation between the components of social belonging (relatedness, perception of interpersonal relationship in the particular social environment, perception whether others in that setting include, value and respect one) and physical activity among women in fitness.

\section{Theoretical framework}

The necessity of social belonging as a quality of life influencing factor for peoples' physical and mental health has been proven in scientific studies (Barden et al., 1985; Hagerty et al., 1992; Hale et al., 2005; Leary et al., 1995). The level of quality of life is associated with an individual's ability to use multiple public resources. Quality of life is an individual's satisfaction of values, goals and needs through a person's ability or lifestyle actualization (Emerson, 1985). Person's satisfaction and well-being results from the degree to which an individual's objective situations agree with the person's wishes or needs (Felce \& Perry, 1995).

People need communication and social relationships. One of the most important goals of peoples' lives is to build as much interpersonal relationships as possible (Cosmides \& Tooby, 2005). Several authors explain the need for social relationships differently, for instance, as search for love (Murray, 1938), the need for recognition and support (Rogers, 1951), the need for belonging (Baumeister \& Leary, 1995; Goodenow, 1993; Maslow, 1954) and motivation to belong (McClelland, 1987), as well as the need for a sense of relatedness (Deci \& Ryan, 1991; Ryan, 1993; Vallerand, 1997), resulting from positive and for a person important interpersonal relationships (Baumeister \& Leary, 1995). Social belonging is the perception of a person's interpersonal relationship in the particular social group or environment- a perception whether others in that setting include, value and respect one (Baumeister \& Leary, 1995). It is important for a person to have one's personal characteristics, abilities recognized by others.

Fitness as an active lifestyle is an important social phenomenon that runs through all levels of the modern society, which has a large impact on the main fields of public life, the national relationships, business life, social status, 
fashion, ethical values and peoples' lifestyle. The way how physical activity (PA) affects indicators of quality of life has repeatedly been studied, considering that the PA is any movement of the body, carried out with the help of skeletal muscle, which requires energy consumption (Caspersen et.al, 1995). PA helps to improve the social, mental and physical components (Cacioppo \& Patrick, 2008). Carrying out PA provides an opportunity to interact with team members, opponents, referees, coaches etc., which provides an opportunity to satisfy the person's need to belong and to build social relationships with others (Allen, 2003, Baumeister \& Leary, 1995). The person's selection of a PA type is determined by what groups one wants to belong to.

In recent years, more and more popular are becoming small group fitness trainings, where every visitor has an opportunity to communicate with other participants (IHRSA, 2013). However, when comparing fitness club group classes to training in a team sport, it can be concluded that the fitness club visitors have a lower sense of belonging, because there is no united goal. Nevertheless, the sense of belonging forms between the coach and fitness club clients and between the clients when for each of them the physical activity result is equally important. Mutual PA is as a foundation of social belonging (Johansson, 1996; Steen-Johnsen, 2001), mutual physical activity morality or behavioural standard in the collective body (Skarderud, 1991).

\section{Methods}

In the study voluntarily participated 51 women from 4 fitness clubs in Riga. Respondents' average age was $30 \pm 9,5$ years. Based on the literature sources on social belonging, in order to determine women's, who were engaged in fitness, quality of life component - social belonging, questionnaires were used, adopted in Latvian and which include questions about one of the social belonging components - relatedness (Deci \& Ryan, 1991), perception of interpersonal relationship in the particular social environment and perception whether others in that setting include, value and respect one (Baumeister \& Leary, 1995).

In order to determine the social belonging, from all selected questionnaire questions selected and grouped were those that meet the social belonging components:

1) relatedness - whether the person has a belonging to the particular social group or environment, which was determined by using two tools, they are 'Group Environment Questionnaire and 'Personal Outcomes Index. The original variant of the 'Group Environment Questionnaire' (Widmeyer et.al, 1985; Carron et.al, 1997) is adopted in Latvian (Vazne, 2008). In the study the questionnaire was modified pursuant to fitness classes and group division specifics, taking into account the fact that several participants do not perceive themselves as a team, but as a group in which each participant has its own goals, 
needs, interests and values. The Group Environment Questionnaire consists of 18 statements about the group and the sense of belonging to it. My Life: Personal Outcomes Index was used in Latvian (Vahlina, 2012). The tool is more focused on the person's well-being assessment and less on the life standard evaluation (Schalock et al., 2007).

2) perception of interpersonal relationship - satisfies, does not satisfy, likes, dislikes, allows to feel important, necessary, belonging was determined with four tools: 'Quality of Life Questionnaire, 'Personal Wellbeing Index', 'Comprehensive Quality of Life A Scale' and 'Group Environment Questionnaire'. In the Quality of Life Questionnaire (Schalock \& Keith 1993) in Latvian (Vahlina, 2012) are included 40 questions/indicators. For each indicator there are three possible answers from which the respondent must select the one which suits their situation best. Each subsection applies to another aspect of quality of life (Schalock \& Keith, 1993). The 'Personal Wellbeing Index' (Personal Wellbeing Index. International Wellbeing Group, 2006) for adult people was used in Latvian (Šksestere, 2012) to measure the subjective dimensions of quality of life. The scale contains eight satisfaction aspects, where each of the aspects is related to one domain of life. 'Comprehensive Quality of Life A Scale' in Latvian (Vahlina, 2012) can be used for the general adult people population. The questionnaire has been developed based on the definition of quality of life: Quality of life is a summary of objective and subjective indicators, where each indicator axis includes seven life domains (Cummins, 1997).

3) perception whether others in that setting include, value and respect one was determined by three tools: 'Personal Outcomes Index', 'General Health Questionnaire' and 'Quality of Life Questionnaire'. The 'General Health Questionnaire 12' (Winifield et.al, 1989) was used in Latvian (Cekule et al, 2006), respondents had to assess their feeling and life over the last 2- 3 weeks. The General Health Questionnaire 12 mostly is widely used around the world for psychological load, overload, general mental state determination. Characterization of the rest of the questionnaires was stated above.

For physical activity amount assessment the short version of the 'International Physical Activity Questionnaire' (IPAQ) (Craig et.al., 2003) in Latvian (Kaupuzs \& Larins, 2010) was used. Respondents marked how much of very difficult or moderately intense physical activity they have carried out over the last 7 days, how much time they spent sitting or walking.

In addition, determined were the objective indicators of quality of life, such as home, employment, level of education, financial situation, family status, 
leisure-time activity types, belonging to a group or a club. Surveying and data collection was done anonymously.

SPSS ver.17.0 data processing programme was used for data analysis. Where descriptive statistics was carried out (frequencies, mode, mean), Kolmogorov-Smirnov criterion was used to determine whether the data is parametric or non-parametric and non-parametric statistics correlation analysis method was used to determine Spearman's rank correlation coefficient.

\section{Results}

By summarizing the data, it can be concluded that all respondents' questionnaires were valid for data processing. From 51 respondents the majority $(45 \%)$ is aged from 26 to 35 years and the minority (12\%) is aged from 36 to 58 years.

A large number of respondents do not participate in leisure-time activities mentioned in the questionnaires. For example, $31,3 \%$ over the last month have not visited a bar or a café, $82,5 \%$ did not visit sports events, $77,5 \%$ did not attend a public worship, $28,8 \%$ have not talked to acquaintances or neighbours, $25 \%$ have not eaten outside their home, $45 \%$ have not been to a cinema, $20 \%$ have not visited friends, $15 \%$ have not engaged in physical activity, $91,3 \%$ of the respondents do not belong to any club or association.

By evaluating the obtained Spearman's rank correlation coefficients (onetailed), it can be concluded that for each social belonging component questions' group there are several weak significant correlations $(0,2<\mathrm{rs}<0,49)$ (Dravnieks, 2012) with PA.

Women's in fitness relatedness and PA

There are weak significant correlations between social belonging component's 'relatedness' questions' group and PA (see Figure 1):

"Group Environment Questionnaire” statement:

'To me, this group is one of the most important social groups to which I belong' and moving on foot. The more important is this group, in which the respondent was engaged in fitness, the more frequently they moved on foot for at least 10 minutes without stopping $(r s=, 272, p<0,05)$.

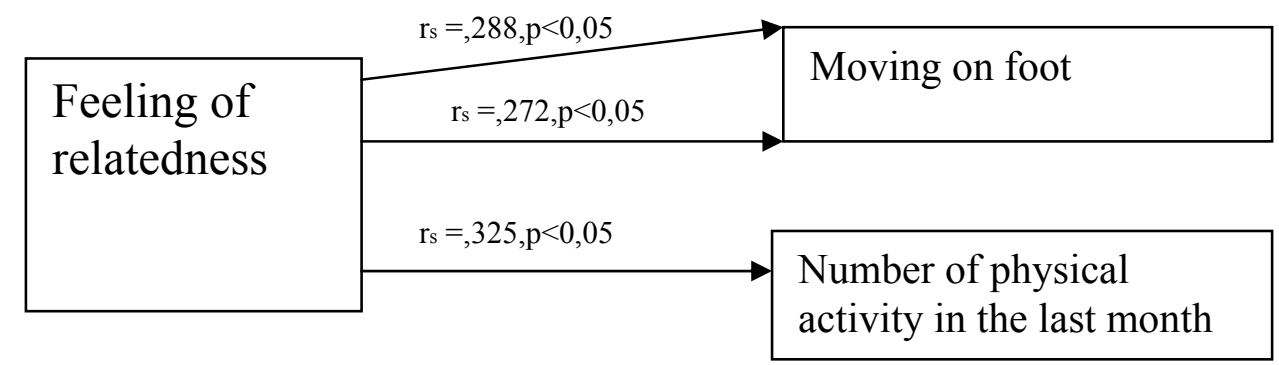

Figure 1. Connection between social belonging component's 'relatedness' questions' group and $\mathbf{P A}$ 
„Personal Outcomes Index” question:

'Do you feel as a part of society? Do you have a sense of belonging to a group, for instance, a team, church etc.', moving on foot and the number of PA in the last month. The smaller the sense of belonging to a group is, the less the respondent moved on foot $(\mathrm{rs}=, 288, \mathrm{p}<0,05)$. The greater the sense of belonging to a group is, the more number of times the respondent has engaged in PA in the last month $(\mathrm{rs}=, 325, \mathrm{p}<0,05)$.

\section{Women's in fitness perception of interpersonal relationship and $P A$}

There are weak significant correlations between the second social belonging component's - 'perception of interpersonal relationship' questions' group and PA (see Figure 2):

'Quality of Life Questionnaire' questions:

'Are you satisfied with the public organization, in which you are engaged in', very difficult PA and moderate PA. The more satisfied the respondent is with the public organization, the less one is carrying out very difficult PA ( $\mathrm{rs}=$ $, 269, \mathrm{p}<0,05)$ and the more frequently carries out moderate PA ( $\mathrm{rs}=, 322$, $\mathrm{p}<0,05)$.

'What about your family members? Do they help you to feel as a wholesome family member, sometimes as a family member or make one feel as foreign to the family', very difficult PA and number of hours of sitting. The more the family members help to feel as a wholesome family member, the more the respondent carries out very difficult PA $(\mathrm{rs}=, 383, \mathrm{p}<0,01)$ and the smaller number of hours one spends sitting ( $\mathrm{rs}=-, 234, \mathrm{p}<0,05)$.

'Personal Wellbeing Index' question:

'How satisfied are you with belonging to a local community', the number of sports competitions over the last month, very difficult PA, moderate PA and moving on foot. The more satisfied the respondent is with the local community, the more frequently one participates in sports competitions $(r s=, 409, p<0,01)$, more often engages in very difficult PA ( $\mathrm{rs}=, 301, \mathrm{p}<0,05)$, carries out moderate PA ( $r s=, 341, p<0,01)$ and is moving more on foot $(r s=, 289, p<0,05)$.

'Comprehensive Quality of Life A Scale' questions:

'How satisfied are you with the relationship with family and friends', the number of sports competitions and moving on foot. The less satisfied the respondent is with the relationship, the less one participates in sports competitions ( $r s=, 255, p<0,05)$ and less moves on foot $(r s=, 285, p<0,05)$.

'How important for you is a close relationship with family and friends' and very difficult PA. The more important a close relationship is for the respondent, the more frequently the respondent carries out very difficult PA ( $\mathrm{rs}=-, 253$, $\mathrm{p}<0,05)$.

'How important it is for you to do something outside the house together with other people' and very difficult PA. The more important it is for the 
respondent to do something outside the house, the more it carries out very difficult PA ( $\mathrm{rs}=-, 241, \mathrm{p}<0,05)$.

\begin{tabular}{|c|c|c|}
\hline \multirow{6}{*}{$\begin{array}{l}\text { Perception of } \\
\text { interpersonal } \\
\text { relationship }\end{array}$} & $r_{s}=, 409, p<0,01$ & Sports competitions \\
\hline & $\mathrm{r}_{\mathrm{s}}=, 301, \mathrm{p}<0,05$ & \multirow[b]{2}{*}{ Very difficult PA } \\
\hline & \multirow{2}{*}{$\mathrm{r}_{\mathrm{s}}=, 341, \mathrm{p}<0,01$} & \\
\hline & & Moderate PA \\
\hline & \multirow{2}{*}{$\mathrm{r}_{\mathrm{s}}=, 289, \mathrm{p}<0,05$} & \\
\hline & & Moving on foot \\
\hline
\end{tabular}

Figure 2. Connection between social belonging component's perception of interpersonal relationship question group and $\mathbf{P A}$

' Group Environment Questionnaire' statement:

'The participants of our group would willingly participate in joint events outside the classes' and moderate PA. The more the respondent would like to participate in joint events with their group, the longer it carries out moderate PA ( $\mathrm{rs}=, 331, \mathrm{p}<0,01)$,

Women's in fitness perception whether others in that setting include, value, respect and one and $P A$

There are weak significant correlations between social belonging component's 'perception whether others in that setting include, value and respect one' questions' group and PA (see Figure 3):

'Personal Outcomes Index' questions:

'Do you have a feeling that people in the local community know you' and very difficult PA. The more frequently one has a feeling that one is recognizable in the society, the more the person carries out very difficult PA ( $\mathrm{rs}=, 345$, $\mathrm{p}<0,01)$. The more frequently a person has a feeling that in the local society he is recognized, the more frequently one carries out very difficult PA ( $\mathrm{rs}=,-392$, $\mathrm{p}<0,01)$.

'How often do you go out of the house together with friends or visit some events, parties, dances' and moving on foot. The more often the respondent goes out with friends, the more one moves on foot $(\mathrm{rs}=, 382, \mathrm{p}<0,01)$.

'General Health Questionnaire' statement:

'You feel that you are an important part of the surrounding society' and very difficult PA. The more the respondent feels that one is an important part of the society, the longer one carries out very difficult PA ( $r s=, 268, \mathrm{p}<0,05)$.

'Quality of Life Questionnaire' questions:

'Do you sometimes feel redundant in social situations', very difficult PA and moderate PA. If a person feels less redundant, then the person carries out moderate PA ( $\mathrm{rs}=, 496, \mathrm{p}<0,01)$ with a greater number of hours per day ( $\mathrm{rs}=$ $, 430, \mathrm{p}<0,01)$. 


\begin{tabular}{|l|l|l|}
\hline $\begin{array}{l}\text { Perception whether } \\
\text { others in that }\end{array}$ & $\mathrm{r}_{\mathrm{s}=, 345, \mathrm{p}<0,01}$ & Very difficult PA \\
\cline { 2 - 3 } $\begin{array}{l}\text { Setting include, } \\
\text { value and respect } \\
\text { one }\end{array}$ & $\mathrm{r}_{\mathrm{s}=-, 496, \mathrm{p}<0,01}$ & Moderate PA \\
\cline { 2 - 3 } & $\mathrm{r}_{\mathrm{s}=-, 382, \mathrm{p}<0,01}$ & Moving on foot \\
\hline
\end{tabular}

Figure 3. Connection between social belonging component's 'perception whether others in that setting include, value and respect one' questions' group and FA

'Do you often attend entertainment events (celebrations, dances and concerts) in your community', very difficult PA and moderate PA. The more often a person attends events, the more frequently one carries out very difficult PA ( $\mathrm{rs}=, 273, \mathrm{p}<0,05)$ and moderate PA ( $\mathrm{rs}=, 337, \mathrm{p}<0,01)$.

'Do you actively participate in these entertainment events', very difficult PA, moderate PA and moving on foot. The more actively the person participates in the events, the more frequently one carries out very difficult PA ( $\mathrm{rs}=, 318$, $\mathrm{p}<0,05)$, carries out moderate PA $(\mathrm{rs}=, 319, \mathrm{p}<0,05)$ and also more often moves on foot ( $\mathrm{rs}=, 239, \mathrm{p}<0,05)$.

Based on the obtained results it can be concluded that social belonging has a correlation with PA. Each of the social belonging components: 'relatedness', 'perception of interpersonal relationship' and 'perception whether others in that setting include, value and respect one' has weak, but significant correlations with PA. All three social belonging components have a relation with the frequency with which the respondent was moving on foot. Two social belonging components: 'perception of interpersonal relationship' and 'perception whether others in that setting include, value and respect one' have weak significant connection to very difficult PA and moderate PA. Component 'perception of interpersonal relationship' has a connection with the frequency with which the respondent participates in sports competitions and the component 'relatedness' has a connection with the number of physical activity in the last month. Due to the obtained results we form an understanding of the way in which social belonging is linked with PA and how PA influences the social belonging.

\section{Discussion}

By comparing the obtained results of the study with other studies on social belonging's in the aspect of quality of life connection with PA it can be concluded that several scholars have pointed out that a correlation exists (Walseth, 2006; Walseth \& Fasting, 2004; Antonsich, 2010; Yuval-Davis, 2006; Anthias, 2006; Pinquart \& Sorensen, 2001; Everard et.al., 2000). Our study aims to determine the correlation between the components of social belonging and PA in the aspect of quality of life for women in fitness. 
Based on the scientific studies, it can be concluded that by communicating and creating positive social contacts in a fitness club a person feels as belonging to a particular group and spends more time doing PA (Yuval-Davis, 2006; Anthias, 2006) which promotes the psychological processes' improvements, reduces stress, improves the mood (McAuley \& Rudolph, 1995). These data also confirm the results obtained in our study that, if a person feels a greater connection with a group, the person is carrying out more PA. Some scholars also point out that by creating friendly relationships with other women from fitness classes there are possibilities to receive emotional support which positively affects a woman's health (Everard et.al., 2000) and that the fitness group and small group classes positively affect socializing for women of all ages (Pinquart \& Sorensen, 2001). The results of our study also indicate that if a person has a greater satisfaction with social contacts and one feels included, supported and valued, then the person is more physically active on a daily basis than those who feel the belonging and support less.

Hereinafter in our study, taking into account the obtained results, the social belonging in the fitness training process will be promoted in order to improve the level of quality of life, in its turn positively affecting women's health, which will be determined by introducing other complementary methods.

\section{Conclusions}

By analyzing literature the components of social belonging were determined - relatedness, perception of interpersonal relationship and perception whether others in that setting include, value and respect one. According to the components, the selected tools' questions were grouped and their connection with PA was determined.

Based on the obtained results it can be concluded that social belonging has a connection to PA. Each of the social belonging components has weak, but significant correlation with PA.

The correlation between all three social belonging components and the respondent's moving on foot during a week was determined, for example, between the social belonging component's 'relatedness' questions and moving on foot: 'To me, this group is one of the most important social groups to which I belong' ( $r s=, 272, p<0,05$ ), 'Do you feel as a part of society? Do you have a sense of belonging to a group, for instance, a team, church etc.'( $\mathrm{rs}=, 288$, $\mathrm{p}<0,05)$; between the social belonging component's 'perception of interpersonal relationship' questions and moving on foot: 'How satisfied are you with belonging to a local community' ( $\mathrm{rs}=, 289, \mathrm{p}<0,05$ ); between the social belonging component's 'perception whether others in that setting include, value and respect one' questions and moving on foot: 'How often do you go out of the house together with friends or go to any events, parties, dances' and moving on foot $(\mathrm{rs}=, 382, \mathrm{p}<0,01)$. 
Two social belonging components': 'perception of interpersonal relationship' and 'perception whether others in that setting include, value and respect one' questions and very difficult PA have weak significant correlation, for example, 'How satisfied are you with belonging to a local community' (rs = ,301, $\mathrm{p}<0,05$ ), 'Do you have a feeling that people in the local community know you' ( $\mathrm{rs}=, 345, \mathrm{p}<0,01)$.

The same social belonging components 'perception of interpersonal relationship' and 'perception whether others in that setting include, value and respect one' and moderate PA also have correlation, for instance, 'Do you sometimes feel redundant in social situations' ( $r s=496, \mathrm{p}<0,01)$, 'How satisfied are you with belonging to a local community' ( $\mathrm{rs}=, 341, \mathrm{p}<0,01$ ).

The component's 'perception of interpersonal relationship' question 'How satisfied are you with belonging to a local community' has a connection to the frequency with which the respondent participates in sports competitions ( $\mathrm{rs}=$ ,409, $\mathrm{p}<0,01$ ) and component's 'relatedness' question 'Do you feel as a part of society? Do you have a sense of belonging to a group, for example, a team, church etc.' has a connection to the number of physical activity in the last month $(\mathrm{rs}=, 325, \mathrm{p}<0,05)$.

Based on the obtained results we form an understanding of the way in which social belonging is connected with PA and that it positively affects PA quantity and type. Those who feel more connected with certain groups, more positively perceive interpersonal relationship and are more satisfied with interpersonal contacts are more engaged in PA. In order to assess social belonging's in the aspect of quality of life for women in fitness correlation with PA one should take into account all the social belonging components.

\section{References}

Allen, J. B. (2003). Social motivation in youth sport. Journal of Sport and Exercise Psychology, 25(4), 551-567.

Anthias, F. (2006). Belongings in a globalising and unequal world: Rethinking translocations. In N. Yuval-Davis, K. Kannabiran, \& U. Vieten (Eds.), The situated politics of belonging (pp. 17-31). London: Sage.

Antonsich, M. (2010). Searching for belonging - An analytical framework. Geography Compass, 4, 644-659.

Barden, R. C., Garber, J., Leiman, B., Ford, M. E., \& Masters, J. C. (1985). Factors governing the effective remediation of negative affect and its cognitive and behavioral consequences. Journal of Personality and Social Psychology, 49, 1040-1053

Bartky, S. (1998). Foucault, femininity, and the modernization of patriarchal power. In $R$. Weitz (Ed.), The politics of women's bodies: Sexuality, appearance, and behavior. New York, NY: Oxford University Press, 25-31.

Baumeister, R., \& Leary, M.(1995). The need to belong: Desire for interpersonal attachments as a fundamental human motivation. Psychological Bulletin, 117(3), 497-529.

Cacioppo, J., \& Patrick, B. (2008). Loneliness: Human nature and the need for social connection. New York: W. W. Norton \& Company, 37-45. 


\section{SOCIETY. INTEGRATION. EDUCATION. Volume III}

Carron, A., Widmeyer, W., Brawley, L. (1997). The development of instrument to assess cohesion in sport team: the group environment questionnaire. Journal of Applied Sport Psychology, 9(1), 244-267.

Caspersen, C., Powell, K., Christenson, G. (1995). Physical activity, exercise, and physical fitness: definitions and distinctions for health-related research. Public Health Rep, 100(126), 31.

Cekule, L., Kamerade, D., Murniece, D., Reinfelde, S., Urbans, I., Vazne, Z. (2006). Vispārējās veselības aptaujas ticamība un faktoru struktūra Latvijā. Teorija praksei mūsdienu sabiedrības izglìtībai, 64-68.

Cosmides, L., \& Tooby, J. (2005). Social exchange: The evolutionary design of a neurocognitive system. In M. S. Gazzaniga (Ed.), The new cognitive neurosciences, III. Cambridge, MA: MIT Press, 35.

Craig, C., Marshall, A., Sjostrom, M., Bauman, A., Booth, M., Ainsworth, B., Pratt, M., Ekelund U., Yngve, A., Sallis J.F., Oja, P. (2003). International Physical Activity Questionnaire: 12-country reliability and validity. Med Sci Sports Exerc, 35, 1381-1395.

Cummins, R. (1997). Comprehensive quality of life scale - adults. 5th Edition. Manual of School of Psychology Deakin University.

Deci, E., \& Ryan, R. (1991). A motivational approach to self: Integration in personality. In $R$. Dienstbier, Nebraska symposium on motivation: Perspectives on motivation, 38. Lincoln, NE: University of Nebraska, 237-288.

Deveaux, M. (1994). Feminism and empowerment: A critical reading of Foucault. Feminist Studies, 20 (2), 223-247.

Dravnieks, J. (2012). MsExcel pievienojumprogramma STATISTIKA 3.1. Mācību līdzeklis LSPA studentiem. [MsExcel additional programme STATISTIKA 3.1] Retrieved from: http://runcis.lspa.lv/statistika.pdf

Dworkin, S. L., \& Wachs, F. L. (2009). Body panic: Gender, health and the selling of fitness. New York, NY: New York University Press.

Emerson, E. (1985). Evaluating the impact of deinstitutionalization on the lives of mentally retarded people. American Journal of Mental Deficiency, 90(3).

Everard, K. M., Lach, H. W., Fisher, E. B., \& Baum, M. C. (2000). Relationship of activity and social support to the functional health of older adults. Journals of Gerontology: Series B: Psychological Sciences and Social Sciences, 55B, S208-S212.

Felce, D., Perry, J. (1995). Quality of life: Its definition and measurement. Res Develop Disab. 16.

Goodenow, C. (1993). The psychological sense of school membership among adolescents: Scale development and educational correlates. Psychology in the Schools, 30, 79-90.

Hagerty, B. M., Lynch-Sauer, J., Patusky, K., Bouwsema, M., \& Collier, P. (1992). Sense of belonging: A vital mental health concept. Archives of Psychiatric Nursing, 6, 172-177.

Hale, C. J., Hannum, J. W., \& Espelage, D. L. (2005). Social support and physical health: The importance of belonging. Journal of American College Health, 53, 276-284

Heywood, L. \& Dworkin, S. (2003). Built to win: The female athlete as cultural icon. Minneapolis, MN: University of Minnesota Press.

Johansson, T. (1996). Den skulpterade kroppen. Stockholm: Carlssons Bokförlag.

Kaupuzs A., Larins V. (2010). Pilot test of International Physical Activity Questionnaire for cultural adaptation in Latvia. Pedagogical Technologies in Socialization and Resocialization of Society, 1, 21-27.

Leary, M., Tambor, E., Terdal, S., \& Downs, D. (1995). Self-esteem as an interpersonal monitor: The sociometer hypothesis. Journal of Personality and Social Psychology, 68, 518-530. 
Lenskyj, H. (1986). Out of bounds: Women, sport and sexuality. Toronto, ON: Women's Press.

Maslow, A. (1954). Motivation and personality. New York: Harper \& Row.

McAuley, E., \& Rudolph, D. (1995). Physical activity, aging, and psychological well-being. Journal of Aging and Physical Activity, 3, 67-96.

Murray, H. (1938). Explorations in personality: A clinical and experimental study of fifty men of college age. New York: Oxford University.

Personal Wellbeing Index. International Wellbeing Group (2006). Melbourne: Australian Centre on Quality of Life, Deakin University

Pinquart, M., \& Sorensen, S. (2001). Influences on loneliness in older adults: A metaanalysis. Basic and Applied Social Psychology, 23, 245-266.

Rogers, C. (1951). Client-centered therapy: Its current practice, implications, and theory. Boston, MA: Houghton Mifflin.

Ryan, R. (1993). Agency and organization: Intrinsic motivation, autonomy and the self in psychological development. In J. E. Jacobs, Nebraska symposium on motivation: Developmental perspectives on motivation (Vol. 40) (pp. 1-56). Lincoln, NE: University of Nebraska.

Schalock, R., Gardner, J., \& Bradley, V. (2007). Quality of life for people with intellectual and developmental Disabilities: Application across individuals, organizations, communities, and systems. Washington, DC: American Association on Intellectual and Developmental Disabilities.

Schalock, R. \& Keith, K. (1993). Quality of Life Questionnaire Worthington Ohio: IDS Publishers.

Skarderud, F. (1991). Sultekunstnerne. Kultur, kropp og kontroll. Oslo: Aschehoug

Skestere, I. (2012). Pètījums par dzìves kvalitātes izvērtējuma metodēm un instrumentiem (1.dalı). [Research about quality of life measurment methods 1st edition] Retrieved from: http://www.lkndz.lv/lv/box/files/filelists/1337599472-petijumsdzkvalit1.pdf

Steen-Johnsen, K. (2001). Treningssenteret - en arena for individualisert trening? En sosiosemiotisk fortolkning. Sosiologi i dag, 31(1), 5-28.

Vahlina, T. (2012). Pètījums par dż̄ves kvalitātes izvērtējuma metodēm un instrumentiem (2.dalı). [Research about quality of life measurment methods 2nd edition] Retrieved from:http:/www.lkndz.lv/lv/box/files/filelists/1339588737-petijumsdzkvalit2.pdf

Vallerand, R. (1997). Toward a hierarchical model of intrinsic motivation. Advances in Experimental Social Psychology, 29, 271-360.

Vazne, Z. (2008). Psychometric properties of the Latvian version of the group environment questionnaire test. Sport Science Journal of Lithuanian Sport Science Council, Lithuanian Olympic Academy of Physical Education and Vilnius Pedagogical University, 2(52), 12-16.

Walseth, K. (2006a). Sport and belonging. International Review for the Sociology of Sport, 41, 447-464.

Walseth, K., \& Fasting, K. (2004). Sport as a means of integrating minority women. Sport in Society, 7, 109-129.

Widmeyer, W., Brawley, L., Carron, A. (1985). The measurment of cohesion in sport tekams: the group environmet. London, ON: Sport Dynamics, 87.

Winefield, H.R., Goldey, R.D.,Winefield, A.H., \& Tiggemann,M.(1989). The General Health Questionnaire: Reliability and Validity for Australian Youth. Australia and New Zealand Journal of Psychiatry,23, 53-58.

Yuval-Davis, N. (2006). Belonging and the politics of belonging. Patterns of Prejudice, 40, 197-214.

IHRSA. (2013). European Market Report 2013. Retrieved from: www.ihrsastore.com 